\title{
Proizvodnja uljane repice na području Valpovštine ovisno o vremenskim prilikama
}

\section{Sažetak}

U ovom radu je analizirana proizvodnja uljane repice kroz četiri vegetacijske sezone od 2016./2017. do 2019./2020. godine na području Valpova (Osječko-baranjska županija). Prosječne temperature u vegetacijama uljane repice od 2016./2017. do 2019./2020. godine su iznosile nešto više od $10^{\circ} \mathrm{C}$. Ukupna količina oborina u vegetaciji uljane repice (rujan - lipanj) se kretala od 443,1 mm (2019./2020. godine) do $624,2 \mathrm{~mm}$ (2017./2018.). Temperature za vrijeme sjetve nisu odstupale od višegodišnjeg prosjeka i bile su povoljne za uljanu repicu, što je uz dovoljnu količinu oborina nakon sjetve rezultiralo dobrim nicanjem uljane repice u svim analiziranim godinama. Specifičnost 2017./2018. vegetacijske sezone je da su visoke temperature zraka u travnju i svibnju dovele do ranijeg sazrijevanja uljane repice, što je pomaknulo rok žetve za 20-ak dana prije uobičajenih rokova krajem lipnja. Suprotno, 2018./2019. obilježena je većim količinama oborina u lipnju $(112,8 \mathrm{~mm})$, što je dovelo do pomicanja rokova žetve za nekoliko dana. U analiziranom razdoblju ostvaren je prosječan sjemena $3,1 \mathrm{t} \mathrm{ha^{-1 }}$, a ovisno o vegetacijskoj sezoni prinos je varirao od 2,69tha ${ }^{-1}$ (2019./2020.) do3,47tha ${ }^{-1}$ (2016./2017.).

Ključne riječi: uljana repica, proizvodnja, temperatura, oborine

\section{Uvod}

Uljana repica (Brassica napus L. subsp. oleifera) se prvenstveno uzgaja radi dobivanja ulja. Njeno ulje pripada u najznačajnije izvore jestivih biljnih ulja te prema ukupnoj svjetskoj proizvodnji glavnih uljarica, zauzima drugo mjesto, odmah nakon soje. Uzgaja se radi sjemena koje sadrži 40 - 48 \% ulja i 18 - 25 \% bjelančevina (Pospišil, 2013.; Szczepaniak i sur., 2017.; Anđelić i sur., 2018.). U posljednjim godinama sve se više ulje iz uljane repice koristi za proizvodnju biodizela, još poznat i kao RME (repičin metil-ester). Ono je motorno gorivo koje se dobiva iz repičinog ili drugih biljnih ulja esterifikacijom s metanolom (Krička i sur., 2002.). Osim navedenog, uljana repica je važna medonosna biljka, a pogače i sačma koje zaostaju nakon izdvajanja ulja se koriste kao stočna hrana (Orlovius, 2003.).

Prema podacima FAOSTATA (2020.), od 2016. do 2018. godine najveću proizvodnju uljane repice imala je Kanada. Nju odmah prate Kina i Indija, na drugom i trećem mjestu. U prosjeku od 2016. do 2018. godine Kanada je imala oko 8,5 milijuna ha površina pod uljanom repicom s proizvodnjom od oko 20,5 milijuna tona. Kina je u istom razdoblju imala prosječno oko 6,5 milijuna ha posijanih površina proizvodnjom oko 13 milijuna tona. Indija je u razdoblju 2016. 2018. godine imala oko 6 milijuna ha s otprilike 7,5 milijuna tona proizvedenog sjemena uljane repice.

U Europskoj uniji reguliran je uzgoj genetski modificiranih usjeva (EU, 2003.), a u Hrvatskoj uzgoj genetski modificirane uljane repice nije dopušten. Genetski modificirana uljana repica prvenstveno se odnosi na tolerantnost na djelatne tvari herbicida (Damgaard i sur., 2005.). 
Uzgoj uljane repice u Hrvatskoj u posljednjem desetljeću ima pozitivan trend rasta uzgojnih površina na našim oranicama (Iljkić i sur., 2019.). U Hrvatskoj se uljana repica u razdoblju 2015.

- 2019. godine uzgajala na prosječno 37183 ha, pri čemu je prosječan prinos sjemena iznosio $2,8 \mathrm{t} \mathrm{ha}^{-1}$. Veličina zasijane površine $\mathrm{u}$ Republici Hrvatskoj najvećim dijelom je ograničena $\mathrm{s}$ vremenskim prilikama u vrijeme sjetve, odnosno količinom oborina, ali i otkupnom cijenom prethodne vegetacijske sezone koja bitno utječe na odabir ratara koje će kulture zasijati na svojim oranicama.

Brown i sur. (2019.) ističu kako je stabilnost prinosa uljane repice glavni problem u Velikoj Britaniji, jer prinosi uljane repice variraju 30 - 50 \% ovisno o vegetacijskoj sezoni. Prema istraživanju u Kini, He i sur. (2017.) navode da u regijama u kojima se proizvodi uljana repica na visinu prinosa najveći utjecaj ima temperatura, zatim oborine u prvim fazama rasta, dok su temperatura i broj sunčani sati najvažniji čimbenici pri nalijevanju i sazrijevanju zrna. Prema istraživanju Weymann i sur. (2015.) na 34 različita lokaliteta diljem Njemačke, otprilike 40 \% varijabilnosti prinosa sjemena moglo bi se objasniti vremenskim uvjetima tijekom određenih faza rasta. Pri tome su najvažnije fenološke faze: početak formiranja mahuna i sjemena (BBCH 50-65) i razvoj sjemena (BBCH 71-79).

Cilj ovog rada bio je analizirati proizvodnju uljane repice na području Valpovštine (Osječkobaranjska županija), odnosno analizirati vremenske prilike i njihov utjecaj na ostvaren prinos sjemena u četiri vegetacijske sezone uljane repice (2016./2017., 2017./2018., 2018./2019. i 2019./2020. godine).

\section{Materijali i metode}

Istraživanje je provedeno na području Valpovštine u istočnom dijelu Slavonije i to na obiteljskom poljoprivrednom gospodarstvu (OPG) „Vjekoslav Šmider“. Gospodarstvo se bavi isključivo ratarskom proizvodnjom te obrađuju 125 hektara oranica od kojih je 40 hektara privatno vlasništvo, a ostatak od 85 hektara oranica je zakup državnog zemljišta i zemljišta fizičkih osoba.

Na OPG-u „Vjekoslav Šmider“ za razdoblje od 2016. do 2020. godine u plodoredu su bile uključene kulture: kukuruz, pšenica, ječam, soja, uljana repica, suncokret i tritikale. Uljana repica je u strukturi sjetve bila zastupljena od 20,5\%, kada je bila zasijana na ukupno 26 ha (2016./2017. godine) do 24,4 \%, kada je bila zasijana na ukupno 31 ha (2017./2018. i 2019./2020. godine).

Uljana repica se na OPG-u,,Vjekoslav Šmider“ u analiziranom razdoblju sijala sredinom rujna (Tablica 1.). Osnovna gnojidba provedena je u jesenskom dijelu, dok je prihrana provedena pravovremeno i to u dva navrata u svakoj vegetacijskoj sezoni (Tablica 2.).

U zaštiti od repičinog sjajnika krajem ožujka ili početkom travnja korišten je svake vegetacije insekticid različite djelatne tvari: Sumialfa 5 FL (djelatna tvar - esfenvalerat), Ches 50 WG (djelatna tvar - pimetrozin), Nurelle D (djelatna tvari - klorpirifos i cipermetrin), Cythrin Max (djelatna tvar - cipermetrin) i Amistar Gold (djelatne tvari - azoksistrobin i difenkonazol). 
Tablica 1. Rokovi sjetve uljane repice od 2016./2017. do 2019./2020. godine.

Table 1. Time of sowing oilseed rape from $2016 / 2017$ to $2019 / 2020$.

\begin{tabular}{|c|c|c|c|}
\hline Datum sjetve & Naziv parcele & Veličina (ha) & Hibrid i sjemenska kuća \\
\hline $\begin{array}{l}2016 . / 2017 . \\
14.9 . \\
15.9 . \\
15.9 . \\
15.9 . \\
\text { Ukupno }\end{array}$ & $\begin{array}{l}\text { Bocanjevci } \\
\text { Ćilimanka } \\
\text { Kudeljaš } \\
\text { Tast }\end{array}$ & $\begin{array}{l}15,65 \\
2,93 \\
3,56 \\
1,04 \\
\mathbf{2 3 , 1 8}\end{array}$ & $\begin{array}{l}\text { NK Petrol (SY) + Hibryrock (KWS) } \\
\text { Hibryrock } \\
\text { Hibryrock } \\
\text { Hibryrock }\end{array}$ \\
\hline $\begin{array}{l}2017 . / 2018 . \\
15.9 . \\
15.9 . \\
16.9 . \\
14.9 . \\
16.9 . \\
16.9 . \\
\text { Ukupno }\end{array}$ & $\begin{array}{l}\text { Repnjak } \\
\text { Glavakovica } \\
\text { Krčevine } \\
\text { Smetište } \\
\text { Fazanerija } \\
\text { Buschbacher }\end{array}$ & $\begin{array}{l}3,79 \\
5,73 \\
10,76 \\
8,12 \\
5,17 \\
1,39 \\
\mathbf{3 4 , 9 6}\end{array}$ & $\begin{array}{l}\text { Bluestar (SY) } \\
\text { Bluestar } \\
\text { Hibryrock } \\
\text { Blue star } \\
\text { Hibryrock } \\
\text { Hibryrock }\end{array}$ \\
\hline $\begin{array}{l}2018 . / 2019 . \\
16.9 . \\
16.9 . \\
17.9 . \\
16.9 . \\
\text { Ukupno }\end{array}$ & $\begin{array}{l}\text { Kudeljaš } \\
\text { Ćilimanka } \\
\text { Bocanjevci } \\
\text { Tast }\end{array}$ & $\begin{array}{l}3,56 \\
2,93 \\
22,23 \\
1,04 \\
\mathbf{2 9 , 7 6}\end{array}$ & $\begin{array}{l}\text { Exception(DK) } \\
\text { Exception } \\
\text { Bluestar+Alvaro(KWS) } \\
\text { Exception }\end{array}$ \\
\hline $\begin{array}{l}2019 . / 2020 . \\
12.9 . \\
11.9 . \\
13.9 . \\
12.9 . \\
12.9 . \\
\text { Ukupno }\end{array}$ & $\begin{array}{l}\text { Panjik } \\
\text { Budžak } \\
\text { Vinogradine } \\
\text { Zgon } \\
\text { Bašća }\end{array}$ & $\begin{array}{l}10,24 \\
13,5 \\
3,36 \\
0,73 \\
4,48 \\
\mathbf{3 2 , 3 1}\end{array}$ & $\begin{array}{l}\text { Bluestar } \\
\text { Bluestar } \\
\text { Bluestar } \\
\text { Bluestar } \\
\text { Bluestar }\end{array}$ \\
\hline
\end{tabular}

SY - Syngenta Agro d.o.o.; KWS - KWS SAAT SE \& Co. KGaA; DK - DeKalb Genetics Corporation

Analiza vremenskih prilika temelji se na srednjim mjesečnim temperaturama zraka i količinama oborina tijekom vegetacijskog razdoblja uljane repice od 2016./2017. do 2019./2020. godine na području Osijeka, te na usporedbi promatranog razdoblja s višegodišnjim prosječnim vrijednostima (1999. - 2018.). Podaci o srednjim mjesečnim temperaturama i oborinama za vegetacijske sezone i višegodišnji prosjek (1999. - 2018.) za postaju Osijek dobiveni su iz Državnog hidrometeorološkog zavoda (DHMZ, 2020.).

Žetva uljane repice na OPG-u „Vjekoslav Šmider“ tijekom promatranog četverogodišnjeg vegetacijskog razdoblja provedena je krajem lipnja. Izuzetak je žetva 2020. godine, kada je uslijed visoke vlažnosti sjemena žetva na dijelu površina obavljena krjem lipnja, a na dijelu površina početkom srpnja. No, unatoč tomu žetva je bila obavljena u optimalnih rokovima. Sklop biljaka u žetvi je bio između 35 i 45 biljaka $\mathrm{m}^{-2}$, što je za hibride optimalan sklop. Svakog puta prije žetve uljana repica se kombajnom malo zakosila kako bi bilo dovoljno sjemena za mjerenje vlage i tako se odredio povoljan trenutak za žetvu. Prinos sjemena određen je na temelju posijanih površina i količini predanog sjemena u Poljoprivredno prehrambeni kombinat (PPK) Valpovo d.o.o., koji skladište sjeme, određuju otkupnu cijenu i kasnije prodaju kupcima unutar ili izvan države. 
Tablica 2. Provedena gnojidba na OPG-u,,Vjekoslav Šmider“ od 2016./2017. do 2019./2020. godine. / Table 2. Fertilization of oilseed rape on Family farm,,Vjekoslav Šmider" from 2016/2017 to $2019 / 2020$.

\begin{tabular}{|c|c|c|c|c|c|}
\hline Vegetacija 2016./2017. & Gnojivo & Količina & $\mathrm{N}$ & $\mathrm{P}_{2} \mathrm{O}_{5}$ & $\mathrm{~K}_{2} \mathrm{O}$ \\
\hline $\begin{array}{l}\text { Osnovna gnojidba } \\
\text { 2.9.2016. }\end{array}$ & NPK 7-20-30 & $180 \mathrm{~kg} / \mathrm{ha}$ & 12,6 & 36 & 54 \\
\hline $\begin{array}{l}\text { Prihrana } \\
\text { 27. 2. } 2017 . \\
\text { 24.3.2017. }\end{array}$ & KAN $(27 \% \mathrm{~N})$ & $\begin{array}{l}1.60 \mathrm{~kg} / \mathrm{ha} \\
11.60 \mathrm{~kg} / \mathrm{ha}\end{array}$ & 32,4 & 0 & 0 \\
\hline Ukupno hraniva & & & 45 & 36 & 54 \\
\hline \multicolumn{6}{|l|}{ Vegetacija 2017./2018. } \\
\hline \multicolumn{3}{|l|}{ Osnovna gnojidba } & 0 & 36 & 54 \\
\hline $\begin{array}{l}\text { Prihrana } \\
\text { 24.2.2018. } \\
\text { 18.3.2018. }\end{array}$ & $\operatorname{KAN}(27 \% \mathrm{~N})$ & $\begin{array}{l}1.120 \mathrm{~kg} / \mathrm{ha} \\
\text { II. } 85 \mathrm{~kg} / \mathrm{ha}\end{array}$ & 55,35 & 0 & 0 \\
\hline Ukupno hraniva & & & 55,35 & 36 & 54 \\
\hline \multicolumn{6}{|l|}{ Vegetacija 2018./2019. } \\
\hline \multicolumn{6}{|l|}{ Osnovna gnojidba } \\
\hline $\begin{array}{l}\text { 3.9. } 2018 . \\
\text { Prihrana } \\
\text { 28. 2. 2019. } \\
\text { 25.3.2019. }\end{array}$ & $\begin{array}{l}\text { NPK } 7-20-30 \\
\text { KAN }(27 \% N)\end{array}$ & $\begin{array}{l}180 \mathrm{~kg} / \mathrm{ha} \\
\text { I. } 140 \mathrm{~kg} / \mathrm{ha} \\
\text { II. } 95 \mathrm{~kg} / \mathrm{ha}\end{array}$ & 63,45 & 36 & 54 \\
\hline Ukupno hraniva & & & 76,05 & 36 & 54 \\
\hline \multicolumn{6}{|l|}{ Vegetacija 2019./2020. } \\
\hline \multicolumn{5}{|l|}{ Osnovna gnojidba } & 54 \\
\hline $\begin{array}{l}\text { Predsjetvena gnojidba } \\
12.9 .2019 .\end{array}$ & $\operatorname{UREA}(46 \% \mathrm{~N})$ & $110 \mathrm{~kg} / \mathrm{ha}$ & 50,6 & & \\
\hline $\begin{array}{l}\text { Prihrana } \\
\text { 25.2.2020. } \\
\text { 20.3.2020. }\end{array}$ & $\operatorname{KAN}(27 \% \mathrm{~N})$ & $\begin{array}{l}\text { I. } 245 \mathrm{~kg} / \mathrm{ha} \\
\text { II.110 kg/ha }\end{array}$ & 95,85 & 0 & 0 \\
\hline Ukupno hraniva & & & 146,45 & 36 & 54 \\
\hline
\end{tabular}

\section{Rezultati i rasprava}

Premda su optimalni rokovi sjetve uljane reice za Republiku Hrvatsku od 25. kolovoza do 10. rujna (Pospišil, 2013.; Balodis i Gaile, 2016.), u analiziranim vegetacijskim sezonama uljana repica je bila posijana u sredinom rujna (Tablica 1.). U određenim godinama na proizvodnom području uljane repice u Hrvatskoj dolazi do manjka oborina, što otežava nicanje i može imati posljedicu na smanjenu gustoću sklopa nakon sjetve. Ukoliko nema oborina, sjetva uljane repice se može prolongirati i do 20. rujna, što ulazi u kasni rok sjetve (Beres i sur., 2019.). Prema Pospišil (2014.) prolongiranje rokova sjetve izvan optimalnih rokova dovodi do sigurnog sniženja prinosa, a autor nadalje ističe kako uslijed bržeg rasta u početnim fazama razvoja hibridi uljane repice mogu biti posijani i krajem prve dekade rujna do sredine rujna. U ovom istraživanju uljana repica je u svakoj vegetacijskoj godini formirala 8 do 12 listova prije zimskog razdoblja, iz čega proizlazi da je sjetva i jesenska gnojidba bila optimalno provedena. Zahtjevi prema vodi za uljanu repicu iznose između 570 i 780 mm (Pospišil i sur., 2014.), a u našim uvjetima, naročito $\mathrm{u}$ istočnoj Hrvatskoj u tom razdoblju često nedostaje vlage za klijanje sjemena što rezultira neravnomjernim nicanjem uljane repice $u$ jesen. 
Tablica 3. Srednje temperature zraka u vegetaciji uljane repice od 2016./2017. do 2019./2020. godine te višegodišnji prosjek (1999. - 2018.) klimatološke postaje Osijek.

Table 3. The mean air temperature in oilseed rape vegetation period from $2016 / 2017$ to 2019/2020 and long term mean for Osijek station.

\begin{tabular}{|c|c|c|c|c|c|}
\hline \multirow[t]{2}{*}{ Mjesec } & \multicolumn{4}{|c|}{ Ukupne mjesečne količine oborina (mm) } & \multirow{2}{*}{$\begin{array}{l}\begin{array}{l}\text { Višegodišnji } \\
\text { prosjek }\end{array} \\
1999 .-2018 .\end{array}$} \\
\hline & 2016./17. & 2017./18. & 2018./19. & 2019./20. & \\
\hline Rujan & 18,1 & 16,1 & 17,4 & 17,5 & 16,9 \\
\hline Listopad & 10,4 & 11,8 & 14,0 & 13,0 & 12,0 \\
\hline Studeni & 6,2 & 6,7 & 7,3 & 10,1 & 6,8 \\
\hline Prosinac & $-0,1$ & 3,6 & 1,4 & 4,0 & 1,7 \\
\hline Siječanj & $-5,1$ & 4,5 & 0,5 & 0,4 & 0,7 \\
\hline Veljača & 4,2 & 0,6 & 4,2 & 6,3 & 2,3 \\
\hline Ožujak & 9,5 & 4,6 & 9,1 & 7,2 & 7,2 \\
\hline Travanj & 11,3 & 16,5 & 12,8 & 12,2 & 12,7 \\
\hline Svibanj & 17,5 & 20,0 & 14,0 & 15,3 & 17,5 \\
\hline Lipanj & 22,4 & 21,0 & 23,1 & 20,2 & 20,9 \\
\hline Prosjek & 9,4 & 10,5 & 10,4 & 10,6 & 9,9 \\
\hline
\end{tabular}

Izvor/Source: Državni hidrometeorološki zavod, 2020.

Iz Tablice 43. može se vidjeti da je 2016./2017. godina bila godina s najmanjim prosjekom od $9,4{ }^{\circ} \mathrm{C}$, što je za $0,5^{\circ} \mathrm{C}$ manje od višegodišnjeg prosjeka (1999. - 2018.). Ta ista godina je prema srednjim mjesečnim temperaturama zraka jedina vegetacijska godina kojoj su se temperature u zimskim mjesecima, točnije u prosincu i siječnju, spustile u minus. Najhladniji je mjesec bio siječanj s temperaturom od $-5,1^{\circ} \mathrm{C}$ (Tablica 3 .).

Također specifično za zimski period 2016. godine je to što je u prosincu bilo iznimno malo oborina, svega $0,5 \mathrm{~mm}$ (Tablica 4.), s time da je ukupno u vegetaciji 2016./2017. godine palo 478,9 mm oborina, što je za 89,3 mm manje od višegodišnjeg prosjeka 1999. - 2018. (568,2 $\mathrm{mm})$. Prosječan prinos sjemena u 2016./2017. godini je bio najviši $\left(3,47 \mathrm{t} \mathrm{ha}^{-1}\right)$, u odnosu na ostale analizirane godine (Tablica 5.).

Vegetacijske godine 2017./2018., zimski mjeseci, prosinac i siječanj, imali su temperature iznad višegodišnjeg prosjeka (Tablica 3.). Srednja mjesečna temperatura u prosincu 2017. godine je iznosila $3,6{ }^{\circ} \mathrm{C}$, što je za $1,9{ }^{\circ} \mathrm{C}$ više od prosjeka, a siječanj $4,5{ }^{\circ} \mathrm{C}$, što je za $3,8{ }^{\circ} \mathrm{C}$ iznad prosjeka. Tek je u veljači došlo do pada temperature na $0,6^{\circ} \mathrm{C}$, a već u ožujku je temperatura počela rasti iako je i dalje bila ispod prosjeka za $2,6{ }^{\circ} \mathrm{C}$. Ukupna količina oborina je iznosila 624,2 $\mathrm{mm}$ što je za $56 \mathrm{~mm}$ iznad višegodišnjeg prosjeka. Mjesec s najmanjom količinom oborina 2018. godine je bio travanj s $21,0 \mathrm{~mm}$, kojeg je slijedio svibanj s $27,4 \mathrm{~mm}$ oborina. Specifičnost 2017./2018. vegetacijske sezone su visoke temperature zraka u travnju i svibnju, koje su dovele do ranijeg sazrijevanja uljane repice, što je pomaknulo rok žetve za 20-ak dana prije optimalnog roka krajem lipnja. Takav raspored oborina se pokazao povoljnim za tu vegetacijsku sezonu jer je već u lipnju 2018. godine bilo kišovito $(126,8 \mathrm{~mm})$. Prosječna prinos sjemena u 2017./2018. godini iznosio je 2,94 $\mathrm{t} \mathrm{ha}^{-1}$ (Tablica 5.), a vlaga sjemena 7,6 \%. 
Tablica 4. Oborine (mm) u vegetaciji uljane repice od 2016./2017. do 2019./2020. godine te višegodišnji prosjek (1999. - 2018.) klimatološke postaje Osijek.

Table 4. The total rainfall in oilseed rape vegetation period from 2016/2017 to 2019/2020 and long term mean for Osijek station.

\begin{tabular}{|c|c|c|c|c|c|}
\hline \multirow[t]{2}{*}{ Mjesec } & \multicolumn{4}{|c|}{ Ukupne mjesečne količine oborina $(\mathrm{mm})$} & \multirow{2}{*}{$\begin{array}{l}\begin{array}{l}\text { Višegodišnji } \\
\text { prosjek }\end{array} \\
1999 .-2018 . \\
\end{array}$} \\
\hline & 2016./17. & 2017./18. & 2018./19. & 2019./20. & \\
\hline Rujan & 43,0 & 80,3 & 27,1 & 75,0 & 61,3 \\
\hline Listopad & 65,4 & 68,7 & 12,2 & 32,3 & 56,6 \\
\hline Studeni & 57,1 & 33,0 & 25,2 & 57,1 & 52,2 \\
\hline Prosinac & 0,5 & 51,7 & 26,7 & 44,9 & 48,8 \\
\hline Siječanj & 25,2 & 61,7 & 42,4 & 13,8 & 45,1 \\
\hline Veljača & 74,4 & 70,2 & 26,8 & 35,6 & 47,3 \\
\hline Ožujak & 67,6 & 83,4 & 8,4 & 37,4 & 47,6 \\
\hline Travanj & 49,7 & 21,0 & 68,6 & 20,7 & 47,8 \\
\hline Svibanj & 50,6 & 27,4 & 150,8 & 53,3 & 75,8 \\
\hline Lipanj & 45,4 & 126,8 & 112,8 & 73,0 & 85,7 \\
\hline Ukupno & 478,9 & 624,2 & 501,0 & 443,1 & 568,2 \\
\hline
\end{tabular}

Izvor/Source: Državni hidrometeorološki zavod, 2020.

U vrijeme sjetve u 2018. godini posijano je rekordnih 55032 ha u našoj državi (Državni zavod za statistiku"Republike Hrvatske, 2020.). Unatoč manjoj količini oborina u rujnu i listopadu 2018. godine, (27,1, odnosno $12,2 \mathrm{~mm})$, repica je dobro iznikla i formirala lisnu rozetu prije zime i prezimila, nakon čega je normalno nastavila svoj razvoj. Najhladniji je mjesec bio siječanj 2019. godine, $\mathrm{s}$ temperaturom od $0,5{ }^{\circ} \mathrm{C}$, s time da je višegodišnji prosjek $0,7{ }^{\circ} \mathrm{C}$, a najtopliji lipanj s temperaturom od $23,1{ }^{\circ} \mathrm{C}$, što je $2,2{ }^{\circ} \mathrm{C}$ više u odnosu na višegodišnji prosjek (Tablica 3.). Također je najmanje oborina bilo u ožujku s količinom od $8,4 \mathrm{~mm}$ što je izrazito malo $u$ usporedbi s ostalim analiziranim godinama. Najviše oborina (Tablica 4.) je bilo u svibnju 2019. godine $(150,8 \mathrm{~mm})$, a nakon toga i u lipnju $(112,8 \mathrm{~mm})$. U vrijeme žetve temperature su se kretale oko $21{ }^{\circ} \mathrm{C}$ te ni tada nisu značajno odstupale od višegodišnjeg prosjeka. Prosječan prinos sjemena u 2018./2019. godini iznosio je 3,15 t ha-1 (Tablica 5.), a vlaga sjemena 7,3 \%.

Veća količina oborina u lipnju 2017./2018. i 2018./2019. godine (Tablica 4.) dovela je do odgode žetve uljane repice za nekoliko dana od uobičajenih rokova za naše podneblje, te se žetva nije mogla obaviti dok se tlo nije dovoljno osušilo da se moglo kombajnom ući u njivu.

Vegetacija 2019./2020. je bila najtoplija, sa srednjom temperaturom u vegetaciji od 10,6 ${ }^{\circ} \mathrm{C}$ što je za $0,7{ }^{\circ} \mathrm{C}$ iznad prosjeka (1999. - 2018.). Mjesec sa najhladnijom temperaturom je bio siječanj 2020 . godine $s, 4{ }^{\circ} \mathrm{C}$, a najtopliji je bio lipanj s temperaturom od $20,2{ }^{\circ} \mathrm{C}$ (Tablica 3.). Uz to što je bio najhladniji, siječanj je također imao i najmanje oborina $(13,8 \mathrm{~mm})$. S druge strane, najviše je oborina palo nakon sjetve u rujnu u količini od $75 \mathrm{~mm}$ te je uljanoj repici dobro došla ta voda i vlaga u tlu za početan rast i razvoj. U zadnjoj vegetacijskoj sezoni (2019./2020.) žetva je počela sredinom lipnja, kada su otprilike 2/3 površina bile ovršene spustila se kiša te se moralo pričekati par dana da se tlo i repica osuše pa se žetva nastavila i bila u potpunosti gotova do samog kraja mjeseca. Osim toga, komuške nisu bile u potpunosti suhe, a da ne bi došlo do njihova savijanja i dok se vlaga zrna nije spustila na prihvatljivi postotak (<18 \%), rokovi žetve su se morali pomaknuti. Zbog razlike u vlažnosti sjemena na jednom dijelu proizvodnih povr- 
šina žetva obavljena početkom srpnja. Prosječan prinos sjemena u 2019./2020. godini iznosio je 2,69 t ha $^{-1}$ (Tablica 5 .), a vlaga sjemena $7,8 \%$.

Osim genetskog potencijala rodnosti određenog genotipa, na prinos i sadržaj ulja u sjemenu značajno utječu i pedološko - klimatski uvjeti uzgoja te provedene agrotehničke mjere, kao i njihova međusobna interakcija (Markulj Kulundžić i sur., 2016.; Madić i sur., 2018.). U kasnijim rokovima sjetve dolazi i do značajnog smanjenja udjela ulja u sjemenu koje je, osim samog prinosa, bitan faktor proizvodnje uljane repice (Scott i sur., 1973.). Prema Vinze (2017.) svaki dan kašnjenja u sjetvi iza optimalnog roka rezultira gubitkom prinosa. Mendham i sur. (1981.) ističu kako je sjetva uljane repice u 7 vegetacijskih sezona (1970. - 1977.) provedena krajem rujna ili početkom listopada rezulatirala prinosom od 120 do $450 \mathrm{~g} \mathrm{~m}^{-2}$. Autori ističu kako je prinos sjemena bio povezan s fazom razvoja usjeva u vrijeme cvatnje te kako je kašnjenje porasta srednjih dnevnih temepratura u proljeće (iznad $5^{\circ} \mathrm{C}$ ), doveo do kasnije cvatnje što je imalo velik utjecaj na smanjenje prinosa. Brown i sur. (2019.) su u Velikoj Britaniji došli do zanimljivog podatka kako je srednja temperatura početkom zime snažno povezana $\mathrm{s}$ variranjem prinosa sjemena uljane repice te kako porast srednje temperature od $1{ }^{\circ} \mathrm{C}$ dovodi do prosječnog smanjenja prinosa od $113(+-21) \mathrm{kg} \mathrm{ha}^{-1}$. Autori ističu da su niske temperature $\mathrm{u}$ zimskom razdoblju povezane s višim prinosima, stoga zaključuju da je prosinačka hladnoća glavna odrednica prinosa uljane repice u Velikoj Britaniji. Weymann i sur. (2015.) navode kako tijekom pojave komuški i formiranja sjemena, na prinos uljane repice značajno utječe temperatura, broj sunčanih sati i stres izazvan sušom. Dostupnost asimilata tijekom formiranja komuški određuje broj sjemenki po $\mathrm{m}^{2}$, a autori ističu kako je temperatura glavni parametar koji utječe na porast uljane repice. Naime, niža temperatura produljuje vrijeme translokacije asimilata $u$ sjeme.

Generalno, u ovom istraživanju povoljne vremenske prilike su pogodovale da žetva bude izvršena u kratkom roku i uz nisku vlagu sjemena (Tablica 5.), koja je u svim proizvodnim godinama bila ispod granice maksimalne vlažnosti i time smanjila troškove sušenja. Svakog puta prije žetve uljana repica se kombajnom malo zakosila kako bi se skupilo dovoljno sjemena za mjerenje vlage i tako se odredio povoljan trenutak za žetvu. $U$ analiziranom petogodišnjem razdoblju (2016./2017. - 2019./2020.) prosječan prinos sjemena uljane repice na području Valpovštine je iznosio 3,06 tha-1.

Tablica 5. Ukupno ostvareni prinosi uljane repice na OPG-u „Vjekoslav Šmider“ $u$ analiziranom razdoblju.

Table 5. Seed yield of oilseed rape on Family farm,,Vjekoslav Šmider“ in analyzed period.

\begin{tabular}{lcc}
\hline Godina & Vlaga (\%) & Prinos $\left(\mathrm{t} \mathrm{ha}^{-1}\right)$ \\
\hline $2016 . / 2017$. & 8,4 & 3,47 \\
\hline $2017 . / 2018$. & 7,6 & 2,94 \\
\hline $2018 . / 2019$. & 7,3 & 3,15 \\
\hline $2019 . / 2020$. & 7,8 & 2,69 \\
\hline Prosjek & -- & 3,06 \\
\hline
\end{tabular}

\section{Zaključak}

Tijekom vegetacijskih godina od 2016./2017. do 2019./2020. analizirana je proizvodnja uljane repice na OPG-u „Vjekoslav Šmider“. Korišteni su podaci Državnog hidrometeorološkog zavoda o temperaturama i količinama oborina od 2016. do 2020. godine te za višegodišnji prosjek od 1999. do 2018. godine. Svaka godina je imala odstupanja po temperaturi ili oborinama 
te je svaka proizvodna godina po nečemu specifična. Analizirano razdoblje nije uvelike odstupalo od višegodišnjeg prosjeka po temperaturama već su oborine bile te s većim odstupanjem. U vegetacijskoj sezoni 2017./2018. uljana repica je uslijed toplog i sušnog proljetnog razdoblja sazrela ranije, stoga je bila požeta prije optimalnih rokova, kao i većina njiva strnih žitarica. Na osnovu provedene analize proizvodnje uljane repice može se zaključiti da je 2018./2019. godina bila specifična za sjetvu, zbog manjka oborina, ali i žetvu uljane repice, zbog viška oborina u lipnju. Međutim takav raspored oborina se nije odrazio na prinos $\left(3,15 \mathrm{t} \mathrm{ha}^{-1}\right)$. Na temelju ovog istraživanja može zaključiti da je svaka proizvodna godina bila uspješna za uljanu repicu, a da su odabrani hibridi dali zadovoljavajući prinos na području Valpovštine te se sva odstupanja temperatura i oborina nisu negativno odrazila na proizvodnju uljane repice.

\section{Napomena}

Ovaj rad prikazuje dio završnog rada studentice Terezije Šmider (Stručni studij Bilinogojstvo-Ratarstvo, Fakultet agrobiotehničkih znanosti Osijek), čija je mentorica bila dr.sc. Ivana Varga.

\section{Literatura}

Anđelić, E., Antunović, M., Stošić, M., Iljkić, D., Varga, I. (2018) Yield components of winter oilseed rape regard to plant population. Columella - Journal of Agricultural and Environmental Sciences, 5 (2): 33-41.

Balodis, O., \& Gaile, Z. (2016) Sowing date and rate effect on winter oilseed rape (Brassica napus L.) yield components' formation. In Proceedings of the Latvian Academy of Sciences. Section B. Natural, Exact, and Applied Sciences. 70 (6): 384-392. Sciendo.

Beres, J., Becka, D., Tomasek, J., Vasak, J. (2019) Effect of autumn nitrogen fertilization on winter oilseed rape growth and yield parameters. Plant Soil Environ., 65: 435-441. https://doi.org/10.17221/444/2019-PSE

Brown, J. K., Beeby, R., \& Penfield, S. (2019) Yield instability of winter oilseed rape modulated by early winter temperature. Scientific reports, 9(1), 1-9. https://doi.org/10.1038/s41598-019-43461-7

EU, 2003. Regulation (EC) No 1830/2003 of the European Parliament and of the Council of 22 September 2003 concerning thetraceability and labelling of genetically modified organisms andthe traceability of food and feed products produced from geneti-cally modified organisms and amending Directive 2001/18/EC.http://europa.eu.int/eur-lex/pri/ en/oj/dat/2003/1_268/1_26820031018en00240028.pdf.

Damgaard, C., Kjellsson, G. (2005) Gene flow of oilseed rape (Brassica napus) according to isolation distance and buffer zone. Agriculture, ecosystems \& environment, 108(4), 291-301. https://doi.org/10.1016/j.agee.2005.01.007

DHMZ (2020) Državni hidrometeološki zavod, https://meteo.hr/index.php (28. 7. 2020.)

FAOSTAT (2020): Food and Agriculture Organization of the United Nations, FAOSTAT data base: http://www.fao. org/faostat/en/\#data/QC (5. 6. 2020.).

He, Y., Revell, B. J., Leng, B., Feng, Z. (2017) The effects of weather on oilseed rape (OSR) yield in China: future implications of climate change. Sustainability, 9(3), 418.

Iljkić, D., Kranjac, D., Zebec, V., Varga, I., Rastija, M., Antunović, M., Kovačević, V. (2019) Stanje i perspektiva proizvodnje žitarica i uljarica u Republici Hrvatskoj. Glasnik zaštite bilja, 42(3): 58-67. https://doi.org/10.31727/gzb.42.3.9

Krička, T., Jukić, Ž., Voća, N. (2002) Proizvodnja biodizelskog goriva u Republici Hrvatskoj. Agronomski fakultet sveučilišta u Zagrebu. Krmiva, 44 (3), 149-154.

Jovičić, D., Marjanović-Jeromela, A., Zdjelar, G., Nikolić, Z., Marinković, R., Sakač Z. (2012) Prinos i kvaliteta sjemena uljane repice ovisno o genotipu i uvjetima uzgoja. Glasnik zaštite bilja, 35(4): 34-39.

Madić, M., Paunović, A., Đurović, D., Marković, G., Knežević, D., Jelić, M. i Stupar, V. (2018) Prinos i komponente prinosa zrna tritikalea gajenog na zemljištu tipa pseudoglej. Journal of Central European Agriculture, 19 (1), $184-193$. https://doi.org/10.5513/JCEA01/19.1.20358.

Markulj Kulundžić, A., Kovačević, J., Viljevac Vuletić, M., Josipović, A., Liović, I., Mijić, A., ... Matoša Kočar, M. (2016) Impact of abiotic stress on photosynthetic efficiency and leaf temperature in sunflower. Poljoprivreda, 22 (2), 17-22. https://doi.org/10.18047/poljo.22.2.3

Mendham, N. J., Shipway, P. A., Scott, R. K. (1981) The effects of delayed sowing and weather on growth, development and yield of winter oil-seed rape (Brassica napus). The Journal of Agricultural Science, 96(2), 389-416. https:// doi.org/10.1017/S002185960006617X

Orlovius, K. (2003) Fertilizing for high yield and quality. Oilseed rape. International Potash Institute. Basel, Switzerland. IPI Bulletin No. 16.

Pospišil, M. (2013) Ratarstvo II. dio-Industrijsko bilje. Čakovec: Zrinski d.d.

Pospišil, M. (2014) Sjetva uljane repice. Glasnik Zaštite Bilja, 37(4): 77-80.

Pospišil, M., Brčić, M., Pospišil, A. i Butorac. J. (2014) Prinos i komponente prinosa istraživanih hibrida i sorata uljane repice. Poljoprivreda, 20 (1): 3-9.

Scott, R. K., Ogunremi, E. A., Ivins, J. D., \& Mendham, N. J. (1973) The effect of fertilizers and harvest date on growth and yield of oilseed rape sown in autumn and spring. The Journal of Agricultural Science, 81(2), 287-293.

Szczepaniak, W., Grzebisz, W., Barłóg, P., Przygocka-Cyna, K. (2017) Mineral composition of winter oilseed rape (Brassica napus L.) seeds as a tool for oil yield prognosis. Journal of Central European Agriculture, 18(1): 196-213. 
Twengström, E., Sigvald, R., Svensson, C., Yuen, J. (1998) Forecasting Sclerotinia stem rot in spring sown oilseed rape. Crop Protection, 17(5): 405-411.

Vinze, É. (2017) The effect of sowing date and plant density on yield elements of different winter oilseedrape (Brassica napus var. napus f. biennis L.) genotypes. Columella - Journal of Agricultural and Environmental Sciences, 4 (1): $21-25$.

Weymann, W., Böttcher, U., Sieling, K., \& Kage, H. (2015) Effects of weather conditions during different growth phases on yield formation of winter oilseed rape. Field Crops Research, 173, 41-48.

Prispjelo/Received: 27.8.2020.

Prihvaćeno/Accepted: 5.10.2020.

\section{Professionalpaper}

\section{Rapeseed production in the Valpovo area depending on weather conditions}

\section{Abstract}

This study analyzes the production of oilseed rape in four vegetation seasons (2016/2017. - 2019/2020) in the area of Valpovo (Osijek-Baranja County). Mean temperature in oilseed rape vegetation from 2016/2017 to $2019 / 2020$ was around $10{ }^{\circ} \mathrm{C}$. The total amount of precipitation in rapeseed vegetation (September June) ranges from $443.1 \mathrm{~mm}(2019 / 2020)$ to $624.2 \mathrm{~mm}$ (2017/2018). The temperature during sowing did not deviate from the multi-year average, and was favorable for oilseed rape. With that regard, the rainfall after sowing was enough for oilseed rape emergence. Specificity of 2017/2018 growing season was very high air temperature in April and May, which led to the earlier harvest of the oilseed rape by about 20 days. On the contraty, 2018/2019 year had high rainfall in June $(112.8 \mathrm{~mm})$, which delyed the harvest for a few days. The average seed yield in the analyzed period was $3.1 \mathrm{tha}^{-1}$ and it varied from $2.69 \mathrm{t} \mathrm{ha}^{-1}$ (2019/2020) to 3.47 tha $^{-1}$ (2016/2017).

Keywords: oilseed rape, production, temperature, precipitation

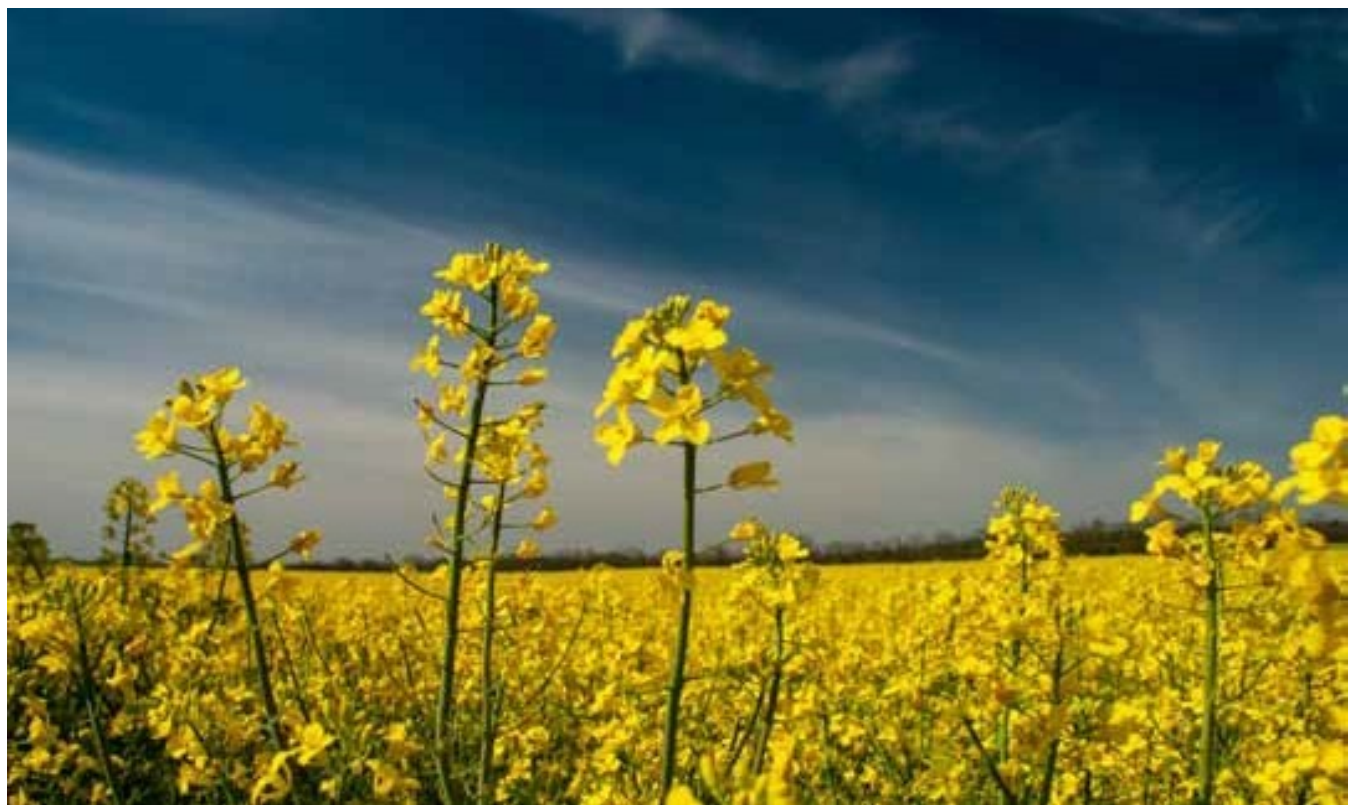

